\title{
ATTITUDES AND PERCEPTIONS OF SHOPPERS' GROCERY SUPERMARKET CHOICES: A COMPARATIVE ANALYSIS BETWEEN BIG C AND TESCO LOTUS
}

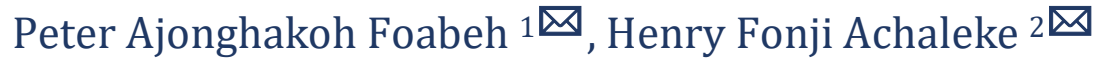 \\ ${ }^{1}$ Lecturer, Finance Department Rajamangala University of Technology, Phra Nakhom, Bangkok, \\ Thailand \\ 2 Lecturer, International Business Program, Faculty of Management Science, Ubon Ratchathani \\ University, Thailand
}

DOI: https://doi.org/10.29121/granthaalayah.v8.i7.2020.599

Article Type: Research Article

Article Citation: Peter Ajonghakoh Foabeh, and Henry Fonji Achaleke. (2020). ATTITUDES AND PERCEPTIONS OF SHOPPERS' GROCERY SUPERMARKET CHOICES: A COMPARATIVE ANALYSIS BETWEEN BIG C AND TESCO LOTUS. International Journal of Research -GRANTHAALAYAH, 8(7), 67-79.

https://doi.org/10.29121/granthaa layah.v8.i7.2020.599

Received Date: 29 June 2020

Accepted Date: 25 June 2020

Keywords:

Satisfaction Importance Attitudes Perceptions Shoppers Choice Supermarket

\begin{abstract}
This study aims to measure the attitudes and perceptions of grocery shoppers towards Big $\mathrm{C}$ and Tesco Lotus among Thais and non-Thais. In achieving this, the importance and satisfaction of shoppers' grocery store choice is examined. The product and service outlets of these two supermarket giants may look identical, but the satisfaction and importance attributed by shoppers may differ considerably. Results from the survey (questionnaire) of 180 respondents show that store image, quality of service, size and location, as well as price and promotion are positively related to satisfaction of shoppers' choice of supermarkets. In addition, price and promotion, parking, and the environment positively affect the importance of shoppers' choice of supermarkets. No valid relationship was found between either satisfaction or importance and demographic factors (gender, age, occupation, and ethnicity).
\end{abstract}

\section{INTRODUCTION}

When it comes to grocery shopping experience in Thailand, it is hard to shun the two major players, Big $\mathrm{C}$ and Tesco Lotus. Other popular supermarket chains in Thailand include Macro, MaxValu, Tops, and Gourmet Markets. Both stores are littered all over the national territory with branches found in every "nook and cranny" of Bangkok. Though both of them provide similar in operating large and smaller stores, Big C is noted for household items and electronics, similar to products and services found in Tesco Lotus. The latter, however, sell Thai products and

(C) 2020 The Author(s). This is an open access article distributed under the terms of the Creative Commons Attribution License, which permits unrestricted use, distribution, and reproduction in any medium, provided the original author and source are credited. 
western goods. This may be attributed to the stakes owned by its parent Tesco from Britain. With both offering a mix of food items, large and small express stores, discount outlets, satisfaction and importance attributed to the products, services and other premiums offered are perceived differently by shoppers. Hence, a shopper may choose to be loyal to one over the other of some reason(s).

The purpose of this study is to situate grocery shoppers in Thailand (Big C/Tesco Lotus) based on their level of importance and satisfaction of store. Note that store and supermarket will be used interchangeably in this study. The main issue here is to find out whether the importance and satisfaction of grocery shopping lead to some quantitative and somewhat satisfactory justification and conclusions about grocery shoppers in Thailand. Grocery shoppers may place more importance and satisfaction on one store over the other.

However, recent changes in consumers' taste and preferences have heightened competition amongst goods and service providers. As grocery supermarkets strive to out-compete each other, price wars are becoming less effective as they turn to shrink total revenues and hence profits. Though the reliance on price as quality cue still exist amongst consumers, (Strachan, 1997), the role of price as a quality cue however, continues to diminish as more cues emerge (Dodds, Monroe, \& Grewal, 1991). This study investigates factors affecting consumers' choice of grocery supermarket, perceived satisfaction and importance attributed to the Big C and Tesco Lotus. This research will be invaluable to the supermarket and shoppers alike. Not only will the study provide insight into what leads to consumers' presence of one shop over the other, it will also provide the relationship between one factor and another giving the supermarkets' management information needed to best allocate resources to help increases consumers' store visit. While this may sound as a benefit to the grocery supermarkets, it is also beneficial to customers. By shifting resources to factors attracting consumers, supermarkets will be providing better services and increasing consumers' choice with the hope of increasing satisfaction.

\section{RATIONALE}

It is commonplace to encounter researchers trying to measure satisfaction (of grocery store choice, for instance) from a set of questions. This study is not different. However, it is not uncommon to measure satisfaction of something that people do not value. The result here can be predictable. The measurement of how important questions asked are to respondents is ideal. As such, it is important to measure to measure how important people perceive particular items and satisfaction. This study therefore considers both the perceived importance and satisfaction of grocery store choice of two big supermarkets in Thailand; Big C and Tesco Lotus.

This research is, therefore, expected to provide information beneficial to grocery supermarket and other grocery store in terms of increasing store visit. This information if effectively used can increase not just the number of visit but also positive feedback from consumers and hence customer satisfaction.

\section{RESEARCH QUESTIONS}

The main aim of this study will be to examine factors responsible for consumers' choice of grocery supermarkets (2) in Thailand. More specifically, the study will try to:

1) Is there significant difference in satisfaction and importance for Big $\mathrm{C}$ and Tesco Lotus?

2) What factors affect grocery shoppers' store (Big C and Tesco Lotus) choice?

3) Is there a relationship between importance and satisfaction of supermarket?

4) Does satisfaction and importance of grocery store choice differ between Big C and Tesco Lotus?

5) Does the effect of importance on satisfaction of grocery store choice differ between the demographic factors or vice versa?

\section{LITERATURE REVIEW}

Recent literature has focused not only on the corporate, social and financial performance of supermarkets chains (Moore \& Robson, 2002) but also on the challenges of management in the retailing industry (Dawson, 2000). As competition continues to heighten amongst major competing supermarkets and retail chains in Thailand, management is constantly in a quest for new non-price competing strategies aimed at not only retaining old 
customers but also attracting new customers at a faster, easier and cheaper way than competitors do. The complexity of today's retailing environment cannot be over emphasis. The increase in globalization has easy the entry of foreign retailing giant and at the same time the proliferation of online shopping with more variety and low cost is shifting consumer buying patterns. All these changes have had tremendous impact on the customers resulting in an everincreasing expectation in the services offered by retailers. While price may be a strong determinant of consumers' product choice, the role of price as a quality signal may diminish as additional signals are added (Dodds, Monroe, \& Grewal, 1991).

However, customers continue to rely on prices as a quality signal in the presence of other extrinsic cues even when there exist a positive link between price and perceive quality (Strachan, 1997), other factors including but not limited to loyalty discount schemes, frequency and availability of special promotion, packing facilities, baby facilities and variety of products play a vital rule not just on consumer perceived quality but also on the loyalty to the shop in question (Moutinho \& Hutcheson, 2007).

In an attempt to understand Korean shoppers and the motivation behind shopping intentions, (Jin \& Kim, 2003), performed a study of shoppers known as discount shoppers and came out with four distinct groups of shoppers as follows; the people who shopped for leisure, the shoppers who did so for social reasons, the conscious shoppers who could spend just the least amount of money to get what they want, and the indifferent shoppers. Based on their findings, assumption could be made that by identifying each of these groups of shoppers, store could focus on enhancing the capabilities on areas that motivated each group of suppers as a means of attracting in-store traffic from these shoppers. This therefore imply that a store targeting the utilitarian shoppers will or should focus more on improving product assortments and information of the products, while at the same time improving Service convenience, neat/spacious atmosphere variety of goods, convivial environment, ease to parking, friendly salespeople, if the intent to attract shoppers from the other three categories. While this may seem straightforward and clear, its applicability is just as problematic and challenging as the applicability of any other strategy in the service industry.

As the retail environment continue to witness tremendous changes, the customers' experience is becoming more important than ever, artificial intelligence will gain more clout, and the rise in consumers' consciousness will continue. While these are global trends, the five most important trends in the retail industry in Thailand include; Strong growth in classes or groups that offer varieties and experiences, brands and consumer loyalty to brands, increase in women substantial purchasing power, even in among non-female groups. New trends show that media such as TV, radio, internet especially social media is influencing e-commerce and the shaping of shoppers' behavior by convenient stores (Bharadwaj et al., 2017). These trends while showing expected changes in the retail industry do not encompass the characteristics of shops necessary to take advantage of such changes.

\section{PRICE AND PROMOTION}

When considering the decision to buy an item, price is the first thing that comes to mind. Price, therefore, is one of the most important market place signs or indicators not only because it is present in every situation, but also because it represents the exact economic signal that must be made by a consumer in order to obtain a particular good or service (Lichtenstein, Ridgway, \& Netemeyer, 1993). Based on this reasoning, it is therefore logical to suggest that higher prices will negatively affect consumer's shopping decisions. However, the heterogeneity nature of consumers makes it complex to ascertain the Impact that prices have on consumer perceptions.

While higher prices affect consumer purchase negatively (Lichtenstein et al., 1993), it could also act as a valuable determinant of quality. (Bagwell \& Riordan, 1991; Moore \& Carpenter, 2006; Rao \& Monroe, 1989). Consequently, the market can be split allowing firms' with significantly higher quality to try and capture high end users at the detriment of low end uses who perceive higher quality to be associated with higher prices (Gardete, 2013). The complexity of price as a marketing cue makes it fundamentally problematic for any business to rely on it as the sole factor affecting consumers purchase behavior. Furthermore, price as a marketing cue is closely associated with promotion in form of discounts, frequency of this discounts and special offers. As many studies (Ataman, Van Heerde, \& Mela, 2010; Gázquez-Abad \& Martínez-López, 2016; Van Heerde, Leeflang, \& Wittink, 2004) have demonstrated, that features associated with consumer packaged goods, are at least in part responsible for consumers allocation of which item they buy in a given store which invaluably affect the net gain from promotion. Based on this, one can therefore argue that it is in the best interest of management to allocate promotional resources taking into 
consideration those consumer-packaged goods features which have a higher impact on shoppers purchase decision making.

\section{PROXIMITY AND SIZE}

Grocery shoppers' choice of supermarket is also influenced by how convenient a store is. Fox, Postrel and McLaughlin (2007) highlighted the importance of proximity to shoppers by predict customer demand estimates based on two dimensions of retail location: I proximity to customers, i.e. commuting times, and (ii) proximity to other outlets, i.e. agglomeration of shops. They further analyzed the impact of the proximity to other stores and how this affects the stores revenue. Proximity could simply be defined as "the degree of closeness of a store to the shopper". In other words, how convenient or near in space, time, or relationship a store is located. This may in tend have a strong relationship with the shoppers' satisfaction and importance of the supermarket.

When it comes to how close a store is theories such as Reilly (1931) and Huff's (1964) retail gravitation ${ }^{1}$, and Christaller's (1966) central place theory ${ }^{2}$ come to mind. The former actually describes how stores fail because failure to be situated by a customer while indoors. In other words, shoppers' choice of grocery shopping is determined by the center whereby the bigger the center the closer the shopper is to the shopping center. Meanwhile Fox, Postrel and McLaughlin (2007) describe the latter as an extension of the former. This is explained as how many, how large and how far settlements are from each other in a residential area. According to Christaller (1966), shoppers will likely choose the store based on what they want. Both theories may therefore be said to be cutting shoppers' transportation costs to its minimum as remarked in the characteristics of consumers' special behavior (Hubbard, 1978).

\section{STORE IMAGE}

The image of a supermarket may be yet another factor that has an impact on shoppers' satisfaction and importance placed on the shop. Since store loyalty can be seen to mean shoppers are satisfied and see a store as important, Imran, Ghani, and Rehman (2013) and Yoo and Chang (2005) advocate the positive link between store image and repeat visits. In other words, there is a positive relationship between a shoppers satisfaction and importance and the image of the store. Though trying to define store image could be an unending battle, particular words or statements have been used to delineate the term such as shoppers' impression of a store in terms of the available products, shopping experience and expectation, and the shop itself (Dunne \& Lusch, 2005), and "quality, atmosphere, personality, image or experience" (Bezes, 2013). The definition could be tied to that of Bezes which measures store image using components that are measurable. Waja (2013) reiterates the measurement of store image using components such as neatness and cleanliness, decoration, wide aisles, air conditioning and lighting.

\section{QUALITY OF PRODUCTS AND SERVICES}

The desirability of products and/or services depends on its quality. Everything being equal, good quality may lead to repeated visits which will intend place importance and satisfaction in the shoppers' experience. According to Matzler and Hinterhuber (1998), when shoppers' expectations are met in a product's quality, the level of satisfaction is high. Product or service quality may therefore be defined as a perception: how the product or service meets the expectations of the shopper. As such, shoppers are always looking forward to spend their money in products where the perceived quality is worth the price. Hence, generally speaking, the perceived quality expectation must be equal or more than the actual quality for satisfaction to be derived. Shoppers will place importance and satisfaction on supermarkets with high quality products or services.

\footnotetext{
${ }^{1}$ Regardless of the distance and mindful of the broader appeal shopping centers bring to consumers, consumers are able to drive longer distances to bigger shopping centers.

${ }^{2}$ Christaller believed that settlements essentially functioned as 'central points' supplying neighboring areas with resources. 


\section{RESEARCH HYPOTHESES}

H1: There is significant difference in satisfaction and importance for Big C and Tesco Lotus.

H2a: Store image is positively related to the shoppers' perceived satisfaction of supermarket.

$\mathrm{H} 2 \mathrm{~b}$ : The quality of products/services positively related to the shoppers' perceived satisfaction of supermarket.

H2c: The size and proximity of a supermarket is positively related to the shoppers' perceived satisfaction of supermarket.

H2d: Price and promotion are positively related to the shoppers' perceived satisfaction of supermarket.

H3a: Price and promotion are positively related to the shoppers' perceived importance of supermarket.

H3b: Availability of parking positively related to the shoppers' perceived importance of supermarket

H3c: The environment is positively related to the shoppers' perceived importance of supermarket.

H4a: Perceived importance is positively related to the shoppers' satisfaction of supermarket.

H4b: Grocery shoppers' perceived satisfaction is positively related to the shoppers' importance of the supermarket.

H5: The relationship between shoppers' perceived importance and satisfaction of supermarket is moderated by demographic factors

\section{SHOPPERS' SATISFACTION AND IMPORTANCE OF SUPERMARKETS}

There is a difference between the importance shoppers have for a store and the satisfaction derived from purchasing products/services. This disparity may not be however too obvious. Another question answered by this study is: "do grocery-shoppers attribute more importance and are they more satisfied after purchasing at Big $\mathrm{C}$ or Tesco Lotus?" Total importance is used to predict overall satisfaction of grocery shoppers. Total importance and overall satisfaction are measured by the "collapsed" or sum of importance and satisfaction scores for the items.

\section{DEMOGRAPHIC FACTORS AND SATISFACTION OF STORE CHOICE}

Repeated visits at a store and/or store loyalty are affected by several factors ranging from store image and price as earlier mentioned. Research has seen the resurrection of even categorical or demographic factors as part of the store choice equation. This is because our behavior, preferences as well as tastes change with time, level of education, gender, and even income. Some of this demographic behavioral change could be personal or coming from economic situations (Kumar, 2014). An individual's characteristics may have an impact on what and where they buy groceries. These characteristics are called demographics or social factors (Iqbal, Ghafoor, \& Shahbaz, 2013). Iqbal et al. advocate that demographic factors such as the level of education, profession, family size and income level impact an individual's choice of store. In connecting the importance of satisfaction with store loyalty, Anić and Radas (2006) place demographic factors at the center of this relationship. Actually, Anić and Radas advocate that shopping experience, family size, and age generally affect the way people behave. They termed this impulse to act as conative loyalty (coined by Harris and Goode, 2004). 


\section{Overall Conceptual Framework}

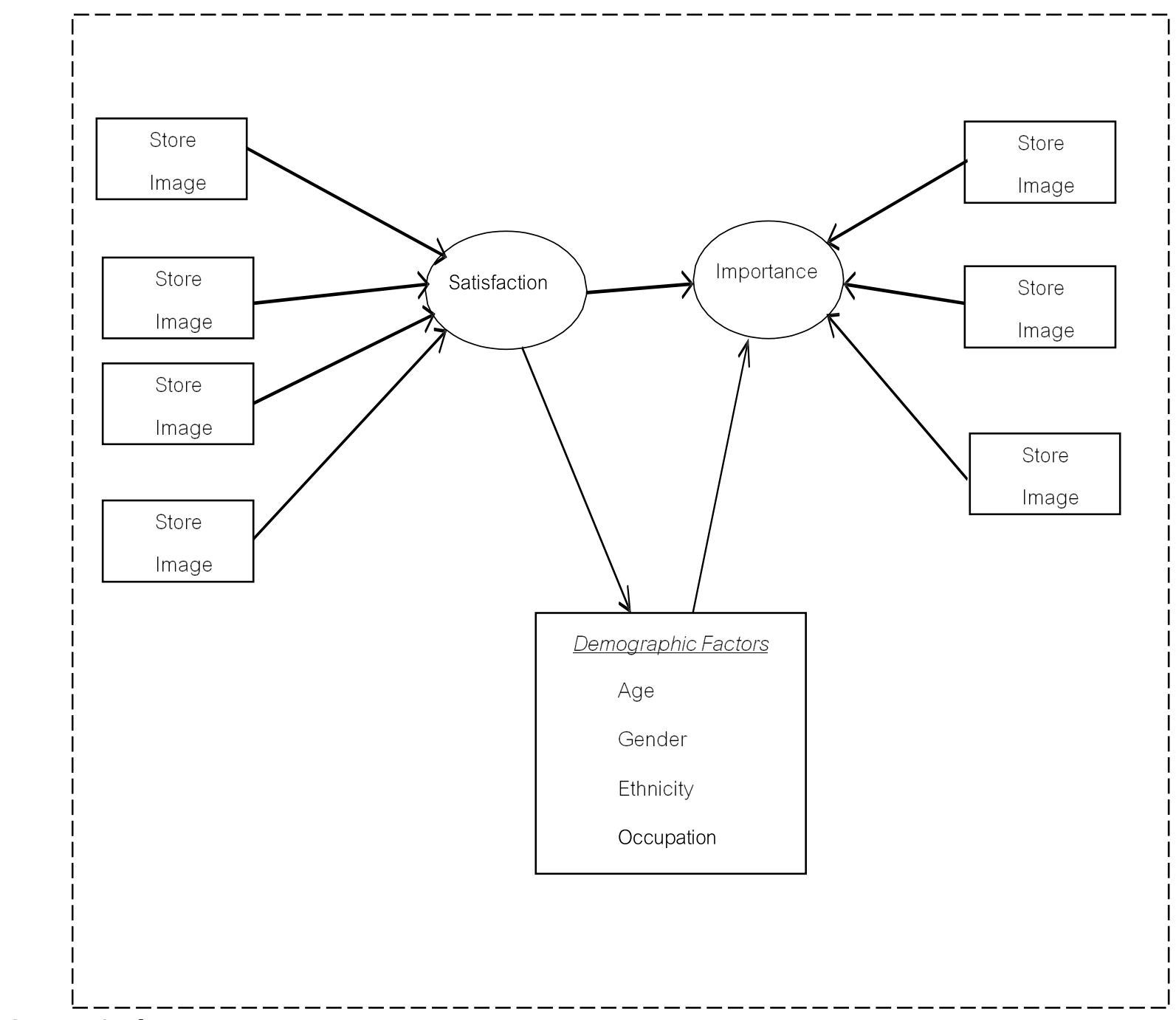

Source Author

Figure 1: Overall schemata (Conceptual Framework) of satisfaction and importance of grocery hoppers' store choice

\section{METHODOLOGICAL UNDERPINNINGS}

\subsection{METHODS AND PROCEDURES}

With the emergence of new innovation and product development, new and old supermarkets are meeting up with the trends of shoppers' demands and preferences. In meeting these demands, supermarkets are bound with the pressure of doing the best from products and services to decoration and environmental issues. Therefore, an understanding and analysis of the importance and satisfaction of grocery shoppers will help supermarkets wishing to establish in Thailand or one of the big cities in the country. It was for this sole reason, first and foremost, that this research was conducted.

A questionnaire designed to measure the two global terms of satisfaction of grocery shoppers and the importance of grocery shoppers was considered. Within these two variables were sub items measuring the overall satisfaction and importance of grocery shoppers. However, in order to discuss trends, similarities and differences as well as measure satisfaction and importance of store choice by grocery shoppers using instruments designed in the questionnaire, this research focuses on testing from normality checks in the data, correlation, regression to core 
Peter Ajonghakoh Foabeh, and Henry Fonji Achaleke

analysis such as factor analysis and structural equation modeling. Mindful of the objectives of this study, some philosophical underpinnings on quantitative research pursuits are highlighted hereunder.

\subsection{METHODOLOGICAL PHILOSOPHY}

The path pursued by this research is purely quantitative. But the term quantitative is very vague. Hence, a breakdown of the philosophical underpinnings and justification of the methodology used is vital. To begin with, the words methodology and methods are sometimes used to mean the same thing. According to McGregor \& Murnane (2010) say methodology denotes philosophy (and practices) while method refers to conduct research using technical procedures. As this research was conducted with quantitative method in mind and, it would be important to narrate the pattern in which this came about. It became a prevalent term in the early 1800s (Rohmann, 1999), but it was until in the 1960s that it was amplified by two well-known philosophers, Popper and Kuhn (Zammito, 2004). This was however done in ways different from positivism (Ibid., 2004). As such, a positivist is said to be someone who accepts the precepts and assumptions behind using measurements and counting as the tools for research. A firm and epistemological background of methodology is provided by a deep understanding of positivism (Caldwell, 1980). The only was a research can be fair is only if the methodology was empirical and scientific, as well as data collected through experiments (Rohmann, 1999). This should be done using hypotheses and should be reliable to reduce biasedness (McGregor \& Murnane, 2010).

The main idea behind quantitative research is the philosophy of positivism. There are four methodological axioms (epistemology, ontology, logic, and axiology) used by researchers. Without going into details, epistemology here means knowing and the method by which we come to know (Trochim, 2000). Epistemology is related to methodology (defined above) and ontology. On the other hand, naturalism is when knowledge is created through interaction with the subjects to get data (Coll \& Chapman 200; Cousins, 2002). The researcher will not give details on naturalism, which is the opposite of positivism. However, finding the differences of how reality is known starts as a philosophical exercise (Oslo, 1995). Now, realism in the form a paradigm is what creates a somewhat clear demarcation between our study (quantitative) and qualitative methodology. Realism, therefore, can be seen as critical (Hunt, 1991), consists of positivism and naturalism (Healy \& Perry, 2000), postpositivism (Denzin \& Lincoln, 1994; Guba \& Lincoln, 1994). Note here that postpositivism is the refusal to accept the doctrines of positivism (Niglas, 2001). Recently, a popular thought says qualitative and quantitative methodologies can be both positivism (Shah and Corley, 2006). It is for this reason that the researcher seeks a quantitative methodology without actually indulging in philosophical debates on positivism and interpretivism paradigms. Axiology denotes the voice of the participants and researcher (Ponterotto, 2005).

Some of the objectives here will be to provide some philosophical world views that have shaped the approaches in research. It is worthy to give an account (however brief or succinct) of these viewpoints of research in this report. These worldviews are known as the basic ideas that guide action (Guba, 1990), paradigms (Lincoln, Lynham, \& Guba, 2011; Mertens, 2010) ontologies and epistemologies (Crotty, 1998) or better still research methodologies (Neuman). The aforementioned terminologies are seen totally differently in social science by objectivist (positivist) and subjectivist (interpretivism). For instance, the assumption of ontology is called realism by a positivist and seen as nominalism by an interpretivism (Burrell \& Morgan, 1979) Motulsky \& Christopoulos (2004) state that a mistake should not be made by using R squared as the main criterion for model fit to data. A high value for R square only says how close the curve is to the data points (ibid.). R squared may be accompanied by meaningless parameter values and very wide confidence intervals. The linear graph follows the data great with an R squared of $88 \%$. But while taking a closer look at the graph, a lot of problems were realized. With a wide confidence interval for parameters in the model become less useful.

When trying to find the values of the parameters that best fit the data, also try to avoid using parameters that don't fit. In this case, if the known parameters are those of the polynomial of degree one and the constant, interpret the polynomial regression more or less as a linear regression. However, the more the parameters, the more flexible the model or equation is in describing the graph (Motulsky \& Ransnas, 1987)

Linear regression and correlation are somehow related though correlation is seen as a precondition for running regression analysis. So there is no need trying to run a linear model when you intend to find a correlation coefficient (Motulsky \& Ransnas, 1987). For a linear model or regression, the p value is not informative because the slope of a linear regression curve differs from zero. However, making a visual choice between a linear and a nonlinear model 
is a very tough decision. Motulsky and Ransnas (1987) conclude that we consider a nonlinear model to a curve whose runs test has a low $\mathrm{p}$ value.

Further analysis extends to factor analysis which is sometimes seen as an easier way of developing constructs and analyzing questionnaire items. The questionnaire designed in this research is used to measure shoppers' choice of grocery supermarkets. The designing of this questionnaire further breaks down a shopper's choice into specific items. In this case, unmeasured variables that contribute to shoppers' choice of grocery shops are known as factors or constructs. In this research, therefore, survey questions of customers' choice of supermarket are used in evaluating the shoppers' choice of grocery supermarkets. The researcher obtained data on different items measuring importance and satisfaction from customers' visitations and choice of store. The analysis commences by running a Factor Analysis to narrow down the number of items in this study. Each question item was measured by a 5-point Likert scale.

The process of factor analysis begins with the initial screening of data. At this stage, data is tested or checked for normality and, then move on to the retention of factors and the rotation method is use as well as a reliability analysis. Note that this process is partitioned in three segments, namely: initial checks, main analysis and post analysis (see Figure 2).

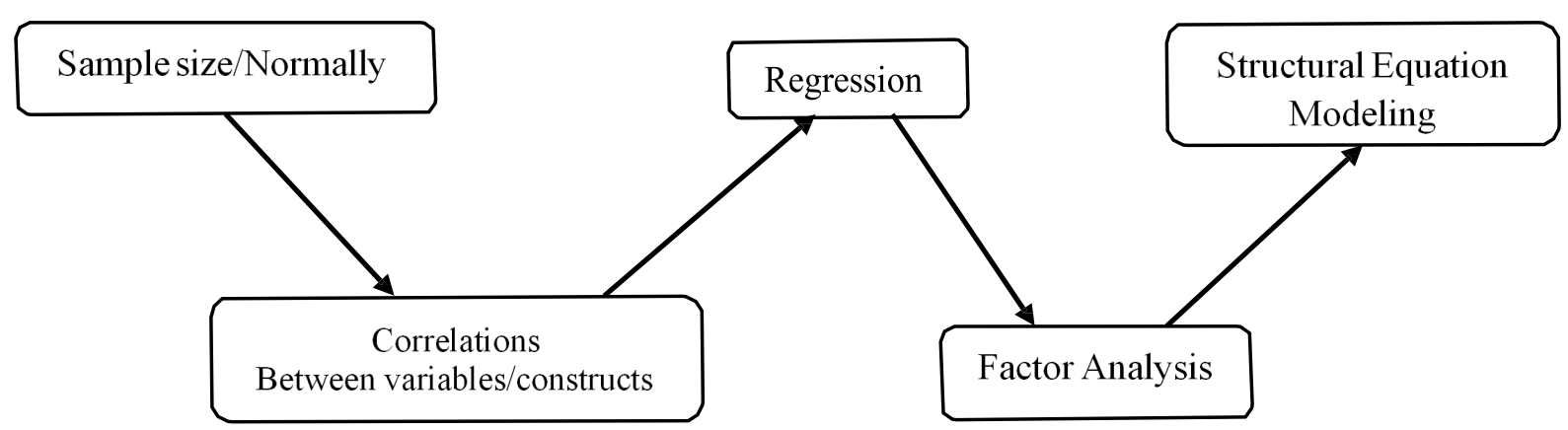

Figure 2: Procedures for Conducting Factor Analysis and SEM (but no SEM in this research)

Figure 2 shows the general procedure for conducting FA with specific details such as screening data, multivariable data analysis, missing values, quality of measurement model and presence of outliers all under preliminary data analysis (PDA); extract factors in the principal component analysis (PCA) or maximum likelihood (ML), orthogonal or oblique rotation for the main analysis; and then Cronbach's alpha and average variance extraction (AVE) for reliability after which biases can be addressed. Besides the above steps, interpretation of factors, calculation of factor scores and determination of model fit are final steps in this process.

In addition, this section shows the theoretical and hypothetical relationships between the measured and latent variables. There are 30 measured variables (also known as observed variables) categorized under seven (7) factors. On the other hand, factors that cannot be observed or measured directly are called latent variables or constructs. They are called latent constructs because they are unobserved/unmeasured variables. This justifies the use of confirmatory factor analysis (CFA) as opposed to principal component analysis (PCA) which presents the relationships between factors and question items all measured variables. Each latent variable is tied to three question items.

Note that CFA is an extension of exploratory factor analysis (EFA) and provides more robust construct validity of a scale within and across distinct items. After constructing a CFA model, paths are created linking factors and questions items with errors. A clear understanding of path analysis explained by Streiner (2006) says, PA is a more advanced multiple regressions which permit the use of more than one dependent variable at a time as well as allowing some variables to be both dependent and independent. For instance, payment options predict membership (DV) and membership advantages (IV) influence payment options. Peculiar to SEM, exogenous and endogenous variables are used in place of ID and IV. Path analysis is, therefore, an analytic and more flexible technique.

Path analysis is not just another advanced multiple regressions as it does not only predict models; it formulates complex causal relations. However, to examine the relationships between the 7 latent variables, structural equation modeling (SEM) will be applied. In other words, SEM is an extension of the paths created in CFA and SEM connects latent variables. 
When factors are measured they are called observed, otherwise they are known as unobserved variables. The introduction of SEM is due to the shortcoming of path analysis not being able to connect unobserved variables. In other words, path analysis deals with only measured variables. The use of SEM in this paper is backed by this interconnection between both the latent constructs and the observed variables. In plain terms, SEM combines path analysis with CFA. Since both methods stem from the concept of factor analysis, a brief explanation of it would be imperative. Simply put, factor analysis bundles the question items into smaller groups of factors called latent constructs.

The connections between the aforementioned variables are hypothesized in a diagram (See Figure 1). Our expectation is the apriori hypothesis made with variables grouped under particular factors. As such, our analysis should be close to these hypotheses using SPSS software. With all these in mind, we will begin by drawing our theory of shoppers' choice of grocery supermarkets.

\section{RESULTS AND DISCUSSION}

This section reveals the factors that affect or influence grocery shoppers' choice of store amongst Thailand's two biggest supermarkets. The influence of demographic factors on satisfaction and importance of shoppers' choice is also assessed. The analysis starts with simple descriptive statistics, correlations, factor analysis and multiple regressions.

$\mathrm{H} 1$ : There is significant difference in satisfaction and importance for Big $\mathrm{C}$ and Tesco Lotus.

A t-test was run twice for satisfaction and importance to investigate the difference in mean satisfaction and mean importance. If there is a difference as highlighted by the hypothesis, then the data will be split for separate analysis for Big $C$ and Tesco. Otherwise, the data will be used to answer subsequent research questions. Note that the other hypotheses will be answered without restating them.

An independent t-test was conducted to investigate whether there was a difference in satisfaction and importance for the two supermarkets. Results from the independent t-test of the difference in satisfaction and importance between shoppers' store choice at Big C and Tesco Lotus show that both satisfaction and importance of Big C Tesco Lotus shoppers are not different. In other words, the test failed to show a statistically significant difference between the average perceived satisfaction and importance of the two supermarkets $(M=3.91, S D=0.58)$, $\mathrm{t}(82)=1.50, \mathrm{p}=0.135$; and $(\mathrm{M}=4.06, \mathrm{SD}=0.46) \mathrm{t}(85)=0.81, \mathrm{p}=0.420$. Since there is no difference in the mean satisfaction and importance scores for the two supermarkets, the dataset will not be split.

\subsection{DESCRIPTIVE STATISTICS}

Tables 1 and 2 show the correlations of the construct variables for satisfaction and importance. To begin with satisfaction, all the four (4) factors were strongly correlated with store satisfaction and among other factors. The overall average store satisfaction for 180 respondents was 3.84 (slightly above neutral) with a minimum of 3.59 from price and promotion and a maximum of 4.10 from the quality of service.

Table 1: Means, SD and correlation of Satisfaction factors of grocery store choice

\begin{tabular}{|l|c|c|c|c|c|c|}
\hline Satisfaction & $\mathrm{M}$ & SD & 1 & 2 & 3 & 4 \\
\hline 1. Store Image & 3.85 & 0.61 & 1 & & & \\
\hline 2. Service Quality & 4.10 & 0.57 & 0.59 & 1 & & \\
\hline 3. Size and Location & 3.85 & 0.57 & 0.67 & 0.69 & 1 & \\
\hline 4. Price and Promotion & 3.59 & 0.76 & 0.67 & 0.43 & 0.46 & 1 \\
\hline 5. Store Satisfaction & 3.84 & 0.52 & 0.88 & 0.79 & 0.81 & 0.83 \\
\hline
\end{tabular}

Note. All correlation values significant at the 0.01 level

For importance, each of the three (3) factors were highly correlated with importance and moderately correlated with each other. The overall average store importance for 180 respondents was 4.04 (slightly above neutral) with a minimum of 3.87 from price and promotion and a maximum of 4.32 from the environmental conditions. 
Table 2: Means, SD and correlation of Importance factors of grocery store choice

\begin{tabular}{|l|c|c|c|c|c|}
\hline Importance & $\mathrm{M}$ & $\mathrm{SD}$ & 1 & 2 & 3 \\
\hline 1. Price and Promotion & 3.87 & 0.56 & 1 & & \\
\hline 2. Parking & 3.91 & 0.61 & 0.32 & 1 & \\
\hline 3. Environment & 4.32 & 0.50 & 0.37 & 0.40 & 1 \\
\hline 4. Store Importance & 4.04 & 0.42 & 0.74 & 0.78 & 0.75 \\
\hline
\end{tabular}

Note that all above constructs show positive correlation meaning that both constructs increase or decrease simultaneously. The correlation between satisfaction and importance is 0.56 and it is statistically significant at the 0.01 level.

\subsection{FACTOR ANALYSIS}

Going by Table 1, KMO for satisfaction and importance are 0.887 and 0.702 , respectively. This indicates that both satisfaction and importance have compact correlations. This means that FA would show unique and reliable factors. According to Kaiser (1974), emphasis is placed on KMO over 0.5 (benchmark), otherwise, collecting more data or introducing other variables maybe taken into consideration. In addition, the significance $(p<0.001)$ of the Bartlett's test for both further confirms the appropriateness of factor analysis.

Table 3: Summary of factors for satisfaction (4) and importance (3)

\begin{tabular}{|l|c|c|c|c|c|}
\hline Satisfaction & \multicolumn{3}{|c|}{ Importance } \\
\cline { 1 - 4 } Factor constructs & Items & Cronbach's $\alpha$ & Factor constructs & Items & Cronbach's $\alpha$ \\
\cline { 1 - 3 } Store image & 6 & $0.87^{*}$ & $\begin{array}{c}\text { Price and } \\
\text { promotion }\end{array}$ & 5 & $0.76^{*}$ \\
\cline { 1 - 2 } Service quality & 5 & $0.85^{*}$ & Parking & 4 & $0.72^{*}$ \\
\hline Size and proximity & 5 & $0.77^{*}$ & Environment & 2 & 0.62 \\
\hline Price and promotion & 3 & $0.71^{*}$ &
\end{tabular}

Note. * pass reliability test $(\alpha>0.7)$

All the above factor constructs meet the minimum conditions for subsequent analyses except environment which cannot be discarded because it has two items that can get an $\alpha$ of 0.62 .

\subsection{REGRESSION}

Multiple regression analysis predicting satisfaction and importance for Big $\mathrm{C}$ and Tesco as presented in Tables 4,5 , and 6. For satisfaction, all four factors were used to predict satisfaction with the four factors accounting for $78 \%$ of the variance in satisfaction, $\mathrm{F}(1,172)=606.86, \mathrm{p}<0.001$. All four factors significantly predict store satisfaction with store image having the highest impact.

Table 4: Multiple regression results for store satisfaction (Model 1)

$$
\text { Note. }{ }^{* *} \mathrm{p}<0.05
$$

\begin{tabular}{|l|c|c|c|}
\hline Variable & $\mathrm{B}$ & $\mathrm{SE}$ & $\beta$ \\
\hline Store Image & 0.75 & 0.03 & $0.88^{* *}$ \\
\hline Service Quality & 0.71 & 0.04 & $0.79^{* *}$ \\
\hline Size and Location & 0.76 & 0.04 & $0.83^{* *}$ \\
\hline Price and Promotion & 0.55 & 0.03 & $0.81^{* *}$ \\
\hline
\end{tabular}

For importance, all four factors were used to predict importance with the three factors accounting for 54\% of the variance in satisfaction, $F(1,176)=212.99, p<0.001$. All three factors significantly predict store importance with parking being the most important factor for grocery shoppers.

Table 5: Multiple regression results for store importance (Model 2) 
Peter Ajonghakoh Foabeh, and Henry Fonji Achaleke

Note. ${ }^{* *} \mathrm{p}<0.05$

\begin{tabular}{|l|c|c|c|}
\hline Variable & B & SE & $\beta$ \\
\hline Price and Promotion & 0.56 & 0.04 & $0.74^{* *}$ \\
\hline Parking & 0.54 & 0.03 & $0.78^{* *}$ \\
\hline Environment & 0.63 & 0.04 & $0.75^{* *}$ \\
\hline
\end{tabular}

Table 6: Multiple regression results for store importance and satisfaction

Note. ${ }^{* *} \mathrm{p}<0.05$

\begin{tabular}{|l|c|c|c|}
\hline Store Satisfaction & $\mathrm{B}$ & $\mathrm{SE}$ & $\beta$ \\
\hline Model 3 & & & \\
\hline Store Importance & 0.69 & 0.08 & $0.56^{* *}$ \\
\hline Model 4 & & & \\
\hline Store Satisfaction & 0.70 & 0.08 & $0.57^{* *}$ \\
\hline Gender & -0.02 & 0.07 & -0.02 \\
\hline Age & 0.08 & 0.05 & 0.15 \\
\hline Occupation & -0.06 & 0.05 & -0.10 \\
\hline Ethnicity & -0.04 & 0.05 & -0.06 \\
\hline No. of visits per week & 0.01 & 0.03 & 0.02 \\
\hline
\end{tabular}

In addition, importance (in models 3 and 4) significantly predicts satisfaction of grocery store choice $\mathrm{b}=0.7$ $[0.55,0.86], p<0.001$. This implies that a more important grocery store increases the shoppers perceive satisfaction. In other words, as importance increases by one score, satisfaction score increases by 0.46 scores. On the other hand, significance (in models 1 and 2) significantly predicts importance of grocery store choice $b=0.46[0.36,0.56], p<$ 0.001. This implies that a more important grocery store increases the shoppers perceive satisfaction. In other words, as importance increases by one score, satisfaction score increases by 0.70 scores. Everything being equal (holding the other variables constant), more important shoppers' choice is associated with increased satisfaction.

For the demographic factors (gender, age, occupation, ethnicity and number of days visit per week), all were not statistically significant in predicting importance or satisfaction of grocery store choice. As such, none of the demographic factors affect store satisfaction or importance. However, both models are statistically significant [F = 78.38, $\mathrm{p}<0.001$ and $\mathrm{F}=13.60, \mathrm{p}<0.001$ ], with variables predicting 31.6 and $33.1 \%$ of the change in satisfaction and importance of grocery store choice in models 1 and 2, respectively. Similar results were obtained for importance. For more information, see Table $3 \mathrm{a}$ and $3 \mathrm{~b}$ in the appendix section.

\section{CONCLUSIONS}

Every attempt made in modeling satisfaction presents new insights; some proven by empirical research and some uncovered by ongoing research. This research presents something unique by predicting satisfaction of grocery shopping from perceived importance shoppers place on supermarkets. Hence, a survey (questionnaire) of 180 respondents show that store image, quality of service, size and location, as well as price and promotion are positively related to satisfaction of shoppers' choice of supermarkets. This suffices to conclude that with better store image, great quality of services provided, big store and accessible locations as well as affordable prices and continuous promotion will increase shoppers visit to the store.

In addition, price and promotion, parking, and environment positively predict importance of shoppers' choice of supermarkets. Provide affordable prices, spacious parking and aisles as well as a convivial environment for shoppers to keep visiting. No valid relationship was found between either satisfaction or importance for demographic factors. Even when demographic factors are used as moderators, the relationship between importance and satisfaction remains the same with statistically insignificant values for the demographic factors. This is contrary to Iqbal, Ghafoor and Shahbaz's (2013) findings. Iqbal, Ghafoor and Shahbaz's (2013) found that demographic factors are significant (negative and positive) determinants of store choice. Recall that though demographics may have influence on shoppers' behavior, the two supermarkets under study in this research do not have differences in 
Attitudes and Perceptions of Shoppers' Grocery Supermarket Choices: A Comparative Analysis Between Big C and Tesco Lotus

shoppers' satisfaction and importance. Hence, demographics may not have a huge influence on shoppers' decision to choose a store.

\section{SOURCES OF FUNDING}

This research received no specific grant from any funding agency in the public, commercial, or not-for-profit sectors.

\section{CONFLICT OF INTEREST}

The author have declared that no competing interests exist.

\section{ACKNOWLEDGMENT}

None.

\section{REFERENCES}

[1] Anić, I.-D., \& Radas, S. (2006) The role of satisfaction and demographic factors in building store loyalty, Privredna kretanja i ekonomska politika, vol. 108, pp. 67-86.

[2] Ataman, M. B., Van Heerde, H. J., \& Mela, C. F. (2010) The long-term effect of marketing strategy on brand sales, Journal of Marketing Research, vol. 47, no. 5, pp. 866-882.

[3] Bagwell, K., \& Riordan, M. H. (1991) High and declining prices signal product quality, The American Economic Review, vol. 81, no. 1, pp. 224-239.

[4] Bezes, C. (2013) L'image du magasin: définition, effets, mesure et perspectives de recherché, Management Avenir, vol. 2, pp. 74-101.

[5] Bharadwaj, A., Chaudhary, A., Kittikachorn, P., \& Rastogi, V. (2017) Five consumer trends to watch in Thailand, Available: https://www.bcg.com/publications/2017/globalization-go-to-markets-five-consumertrends-watch-thailand.aspx [June 3, 2019]

[6] Caldwell, B. (1980) Positivist philosophy of science and the methodology of economics, Journal of Economic Issues (JEI), vol. 14, no. 1, pp. 53-76.

[7] Christaller, W. (1966). Central places in southern Germany. Prentice Hall.

[8] Dawson, J. (2000) Retailing at century end: Some challenges for management and research, The International Review of Retail, Distribution and Consumer Research, vol. 10, no. 2, pp. 119-148.

[9] Dodds, W. B., Monroe, K. B., \& Grewal, D. (1991) Effects of price, brand, and store information on buyers' product evaluations, Journal of Marketing Research, vol. 28, no. 3, pp. 307-319.

[10] Dunne, P., \& Lusch, R. (2005). Retailing, Fitht edition.

[11] Fox, E. J., Postrel, S., \& McLaughlin, A. (2007). The impact of retail location on retailer revenues: An Empirical

[12] Gardete, P. M. (2013) Cheap-talk advertising and misrepresentation in vertically differentiated markets, Marketing Science, vol. 32, no. 4, pp. 609-621.

[13] Gázquez-Abad, J. C., \& Martínez-López, F. J. (2016) Understanding the impact of store flyers on purchase behaviour: An empirical analysis in the context of Spanish households, Journal of Retailing and Consumer Services, vol. 28, pp. 263-273.

[14] Harris, L. C., \& Goode, M. M. (2004) The four levels of loyalty and the pivotal role of trust: A study of online service dynamics, Journal of Retailing, vol. 80, no. 2, pp. 139-158.

[15] Hubbard, R. (1978). A review of selected factors conditioning consumer travel behavior. Journal of Consumer

[16] Imran, M., Ghani, U., \& Rehman, K. U. (2013) Consumer perception of store image and store loyalty, Journal of Managerial Sciences, vol. 12, no. 1, 75-85.

[17] investigation. Unpublished manuscript, Edwin L. Cox School of Business, Southern Methodist University, Dallas, TX. 
[18] Iqbal, H. K., Ghafoor, M. M., \& Shahbaz, S. (2013) Impact of demographic factors on store selection: An insight in Pakistani society, Journal of Marketing Management, vol. 1, no. 1, pp. 34-45.

[19] Jin, B., \& Kim, J.-0. (2003) A typology of Korean discount shoppers: Shopping motives, store attributes, and outcomes, International Journal of Service Industry Management, vol. 14, no. 4, pp. 396-419.

[20] Kaiser, H. F. (1974) An index of factorial simplicity, Psychometrika, vol. 39, no. 1, pp. 31-36.

[21] Kumar, R. (2014) Impact of demographic factors on consumer behaviour-a consumer behaviour survey in Himachal Pradesh, Global Journal of Enterprise Information System, vol. 6, no. 2, pp. 35-47.

[22] Lichtenstein, D. R., Ridgway, N. M., \& Netemeyer, R. G. (1993) Price perceptions and consumer shopping behavior: A field study, Journal of marketing research, vol. 30, no. 2, pp. 234-245.

[23] Matzler, K., \& Hinterhuber, H. H. (1998) How to make product development projects more successful by integrating Kano's model of customer satisfaction into quality function deployment, Technovation, vol. 18, no. 1, pp. 25-38.

[24] McGregor, S., \& Murnane, J. (2010) Paradigm, methodology and method: Intellectual integrity in consumer scholarship, International Journal of Consumer Studies, vol. 34, no. 4, pp. 419-427.

[25] Moore, G., \& Robson, A. (2002) The UK supermarket industry: An analysis of corporate social and financial performance, Business Ethics: A European Review, vol. 11, no. 1, pp. 25-39.

[26] Moore, M., \& Carpenter, J. (2006) The effect of price as a marketplace cue on retail patronage, Journal of Product \& Brand Management, vol. 15, no. 4, pp. 265-271.

[27] Moutinho, L., \& Hutcheson, G. D. (2007) Store choice and patronage: A predictive modelling approach, International Journal of Business Innovation and Research, vol. 1, no. 3, pp. 233-252.

[28] Rao, A. R., \& Monroe, K. B. (1989) The effect of price, brand name, and store name on buyers' perceptions of product quality: An integrative review, Journal of Marketing Research, vol. 26, no. 3, pp. 351-357.

[29] Reilly, W. J. (1931). The law of retail gravitation. WJ Reilly.

[30] Research, 5(1), 1-21.

[31] Strachan, J. (1997) Multiples target the home front, Marketing Week, vol. 19, p. 34.

[32] Streiner, D. L. (2006) Building a better model: An introduction to structural equation modelling, The Canadian Journal of Psychiatry, vol. 51, no. 5, pp. 317-324.

[33] Van Heerde, H. J., Leeflang, P. S., \& Wittink, D. R. (2004) Decomposing the sales promotion bump with store data, Marketing Science, vol. 23, no. 3, pp. 317-334.

[34] Waja, N. (2013) The impact of store image on customer perception, Master's thesis, University of the Western Cape.

[35] Yoo, S. J., \& Chang, Y. J. (2005) An exploratory research on the store image attributes affecting its store loyalty, Seoul Journal of Business, vol. 11, no. 1, pp. 19-41. 